\title{
Comparative Analysis of Elementary School Student Knowledge Regarding Flood Mitigation in the Citarum Watershed
}

\author{
Sukono $^{\mathrm{a}, *}$, Eman Lesmana ${ }^{\mathrm{a}}$, Herlina Napitupulu ${ }^{\mathrm{a}}$ \\ ${ }^{a}$ Department of Mathematics, Universitas Padjadjaran, Indonesia \\ Corresponding author e-mail address: sukono@unpad.ac.id
}

\begin{abstract}
Flooding is a natural event, one of which is caused by the overflow of rivers. This disaster often occurs in the Dayeuhkolot area, Bandung Regency. Geographical conditions that are close to the flow of the Citarum River and the plains that are lower than the surrounding area cause this area to be flooded especially during the rainy season. This paper aims to analyze the effectiveness of disaster training given at a young age and analyze the effectiveness of training methods provided in the form of games and PowerPoint media. This activity is aimed at grade 6th students at Bojong Asih Elementary School starting with the questionnaire I which functions as a pre-test and ends with questionnaire II which functions as a post-test. Questionnaires were given at the beginning and at the end to see the extent to which the material provided new influence and knowledge to Bojong Asih Elementary School students. The results of the questionnaire showed that before counseling about flood mitigation, samples were categorized as having a good knowledge of $91 \%$ and having poor knowledge of $9 \%$. After counseling about flood disaster mitigation using games and PowerPoint media there was an increase in knowledge, samples that had good knowledge were $98 \%$ and those with less good knowledge were $2 \%$. Based on the pre-test and post-test results, this activity was proven successful in increasing the knowledge of Bojong Asih Elementary School related to flood mitigation.
\end{abstract}

Keywords: Citarum River, Bandung Regency, rain, flood, mitigation.

\section{Introduction}

Disaster is a situation that is detrimental to many parties. Disaster is a condition that disrupts the socioeconomic life of the community caused by natural phenomena or human actions (Alexandra, 2015). Disasters can occur through a long process or a certain situation in a very fast time without any signs. The impact of a disaster can varies, depending on environmental and community conditions and vulnerability.

One of the most frequent disasters experienced by people in Indonesia, especially in certain areas such as Dayeuhkolot Bandung is flooding (Adi, 2013). Floods often become disasters that occur and continue 
to recur (Chalkias et al., 2014; Kablan et al, 2017). Muin et al. (2015) and Bainus et al. (2020) have researched flood disaster relief.

Frequent floods that occur and provide losses so mitigation is needed to minimize losses from flooding (Tauhid et al., 2017; Bambals, 2015; Manfreda et al., 2011). Mitigation has an important role in efforts to reduce the risk of floods that often occur in the Dayeuhkolot area of Bandung. Dayeuhkolot is a floodprone area in Bandung. Together with Baleendah, this district has become a standby area when the rainy season arrives. A study of the character of the Citarum Watershed in 2016, found that 94\% (around 879.8 ha) of the Dayeuhkolot area had the potential to be flooded every year. This region includes the upper Citarum Watershed.

This understanding of mitigation is very important especially to young people who do not yet know what is needed early in the event of a disaster (Jimba et al., 2011; Pitsuwan and Caballero-Anthony, 2014). Disaster mitigation is a series of efforts to reduce disaster risks, both through physical development and awareness-raising and capacity building to face the threat of disasters (Article 1 Paragraph 6 Government Regulation of the Republic of Indonesia No. 21 of 2008 concerning Implementation of Disaster Management /Pasal 1 Ayat 6 Peraturan Pemerintah Republik Indonesia No. 21 Tahun 2008 tentang Penyelenggaraan Penanggulangan Bencana). Flood mitigation training must be carried out and given to the community, especially young people. Telling things about floods starting from what floods are, causes of floods, things to do when a flood occurs, things to do after a flood, and instilling thought about the importance of preventing floods. So that all losses caused by flooding will no longer be felt by the community (Sarminingsih et al.. 2014; Hassani, 2016)

The purpose of the research regarding the effectiveness of disaster mitigation training in Bojong Asih 01 Elementary School and Bojong Asih 02 Elementary School are

1. analyze the effectiveness of disaster training given at a young age, and

2. analyze the effectiveness of training methods provided in the form of games and PowerPoint media.

\section{Research Methods}

The method we use to collect data is a questionnaire in the form of pre-test and post-test. Pre-test and post-test contain questions related to flooding disaster mitigation. Another method that we use for disaster mitigation socialization is by using PowerPoint media. The method for processing our data uses Microsoft Excel 2010 software.

\section{Results and Discussion}

\subsection{Scores Data}

The data we use are data from the results of the pre-test scores that we provide before the socialization activities and the post-tests that we provide after the socialization activities. Scores data before and after socialization using PowerPoint media can be seen in Table 1.

Table 1: Scores data of students' knowledges about flood disaster mitigation

\begin{tabular}{llcccccc}
\hline \multirow{2}{*}{ No } & \multirow{2}{*}{ Name } & \multicolumn{3}{c}{ Pre-test } & \multicolumn{3}{c}{ Post-test } \\
\cline { 3 - 8 } & & True & False & Score & True & False & Score \\
\hline 1 & Adi Hardiansah & 7 & 3 & 70 & 7 & 3 & 70 \\
2 & Ajeng Tri Andini & 8 & 2 & 80 & 8 & 2 & 80
\end{tabular}




\begin{tabular}{|c|c|c|c|c|c|c|}
\hline 3 & Akbar Fathul Rizky & 7 & 3 & 70 & 8 & 2 \\
\hline 4 & Alfi & 6 & 4 & 60 & 8 & 2 \\
\hline 5 & Aliska & 5 & 5 & 50 & 6 & 4 \\
\hline 6 & Annisa Putri M. & 8 & 2 & 80 & 8 & 2 \\
\hline 7 & Azzrul Mardia & 8 & 2 & 80 & 8 & 2 \\
\hline 8 & Bella Tri W. & 7 & 3 & 70 & 8 & 2 \\
\hline 9 & Diana Lisna Dewi & 7 & 3 & 70 & 7 & 3 \\
\hline 10 & Dirga Maulana & 7 & 3 & 70 & 8 & 2 \\
\hline 11 & Dwi Ramayanti & 7 & 3 & 70 & 7 & 3 \\
\hline 12 & Eka Alamsyah & 9 & 1 & 90 & 9 & 1 \\
\hline 13 & Fahri & 5 & 5 & 50 & 5 & 5 \\
\hline 14 & Fajar Iqbal M. & 7 & 3 & 70 & 7 & 3 \\
\hline 15 & Farel & 8 & 2 & 80 & 8 & 2 \\
\hline 16 & Fauzi & 6 & 4 & 60 & 6 & 4 \\
\hline 17 & Fedli & 8 & 2 & 80 & 8 & 2 \\
\hline 18 & Fergie & 7 & 3 & 70 & 7 & 3 \\
\hline 19 & Fikri R. M. & 8 & 2 & 80 & 8 & 2 \\
\hline 20 & Fitriya K. & 7 & 3 & 70 & 8 & 2 \\
\hline 21 & Haikal & 7 & 3 & 70 & 8 & 2 \\
\hline 22 & Ikhsan Al Rizky & 7 & 3 & 70 & 8 & 2 \\
\hline 23 & Indah Sri Restina & 8 & 2 & 80 & 9 & 1 \\
\hline 24 & Irpan & 5 & 5 & 50 & 7 & 3 \\
\hline 25 & Jamius & 7 & 3 & 70 & 7 & 3 \\
\hline 26 & Lia Ratisah Fauziah & 5 & 5 & 50 & 7 & 3 \\
\hline 27 & M. Ridwan & 7 & 3 & 70 & 8 & 2 \\
\hline 28 & Meilany & 7 & 3 & 70 & 7 & 3 \\
\hline 29 & Nadiya & 8 & 2 & 80 & 8 & 2 \\
\hline 30 & Nisa Aulia S. & 8 & 2 & 80 & 8 & 2 \\
\hline 31 & Pahmi Wahyudin & 8 & 2 & 80 & 9 & 1 \\
\hline 32 & Panji & 8 & 2 & 80 & 9 & 1 \\
\hline 33 & Raja & 8 & 2 & 80 & 8 & 2 \\
\hline 34 & Raka Agustin & 7 & 3 & 70 & 8 & 2 \\
\hline 35 & Ramdani & 8 & 2 & 80 & 8 & 2 \\
\hline 36 & Randi Hapid & 8 & 2 & 80 & 8 & 2 \\
\hline 37 & Rangga & 7 & 3 & 70 & 7 & 3 \\
\hline 38 & Rani & 8 & 2 & 80 & 8 & 2 \\
\hline 39 & Reyhan & 7 & 3 & 70 & 7 & 3 \\
\hline 40 & Ria Oktaviani & 6 & 4 & 60 & 6 & 4 \\
\hline 41 & Rifaldo & 9 & 1 & 90 & 9 & 1 \\
\hline
\end{tabular}




\begin{tabular}{|c|c|c|c|c|c|c|c|}
\hline 42 & Robi Ardiansyah & 7 & 3 & 70 & 8 & 2 & 80 \\
\hline 43 & Rudi & 4 & 6 & 40 & 6 & 4 & 60 \\
\hline 44 & Saila Dwi Noviani & 7 & 3 & 70 & 7 & 3 & 70 \\
\hline 45 & Salma & 8 & 2 & 80 & 9 & 1 & 90 \\
\hline 46 & Sany Puspita Delia & 8 & 2 & 80 & 8 & 2 & 80 \\
\hline 47 & Sarah H. A. & 7 & 3 & 70 & 7 & 3 & 70 \\
\hline 48 & Selin Septia Rani & 6 & 4 & 60 & 6 & 4 & 60 \\
\hline 49 & Sindi Putri R. & 9 & 1 & 90 & 8 & 2 & 80 \\
\hline 50 & Suci Meilani & 8 & 2 & 80 & 8 & 2 & 80 \\
\hline 51 & Sulis & 7 & 3 & 70 & 8 & 2 & 80 \\
\hline 52 & Tania & 7 & 3 & 70 & 8 & 2 & 80 \\
\hline 53 & Tora Satrio & 8 & 2 & 80 & 8 & 2 & 80 \\
\hline 54 & Yunita Rahmat & 8 & 2 & 80 & 8 & 2 & 80 \\
\hline
\end{tabular}

\subsection{Average Knowledge Score of Samples}

The average score of students' knowledges about flood disaster mitigation both before and after being given exposure using PowerPoint media can be seen in Table 2.

Table 2: Average score of students' knowledges about flood disaster mitigation

\begin{tabular}{ccc}
\hline & Pre-test & Post-test \\
\cline { 2 - 3 } Average & 72 & 76 \\
\hline
\end{tabular}

\subsection{Knowledge Level}

Scores can be categorized as good if the sample has a score greater than or equal to 60, and is not good or poor if the sample has a score of less than 60 .

The frequency distribution of students' knowledge about flood disaster mitigation both before and after being given exposure using PowerPoint media can be seen in Table 3.

Table 3: Frequency distribution of students' knowledge about flood disaster mitigation

\begin{tabular}{|l|c|c|c|c|}
\hline \multirow{2}{*}{ Knowledge } & \multicolumn{2}{|c|}{ Pre-test } & \multicolumn{2}{c|}{ Post-test } \\
\cline { 2 - 5 } & $\mathbf{N}$ & $\boldsymbol{\%}$ & $\mathbf{N}$ & $\boldsymbol{\%}$ \\
\hline Good & 49 & $91 \%$ & 53 & $98 \%$ \\
\hline Not good & 5 & $9 \%$ & 1 & $2 \%$ \\
\hline Total & 54 & $100 \%$ & 54 & $100 \%$ \\
\hline
\end{tabular}

Based on the calculation of the results of the pre-test conducted, before the socialization, there were 49 students or about $91 \%$ had good knowledge and as many as 5 students or about $9 \%$ had poor knowledge and with an average score of 72 . But after the socialization was done according to the calculation results from the post-test with good knowledge increased to 53 students or around $98 \%$, while those who had poor knowledge became as much as 1 student or about $2 \%$ and with an average score of 76 . 
If seen from the results of the pre-test and post-test calculations, the score of student knowledge, the average score of students, and the distribution of the score of average knowledge increases. This increase can be seen from the diagram in Figure 1.
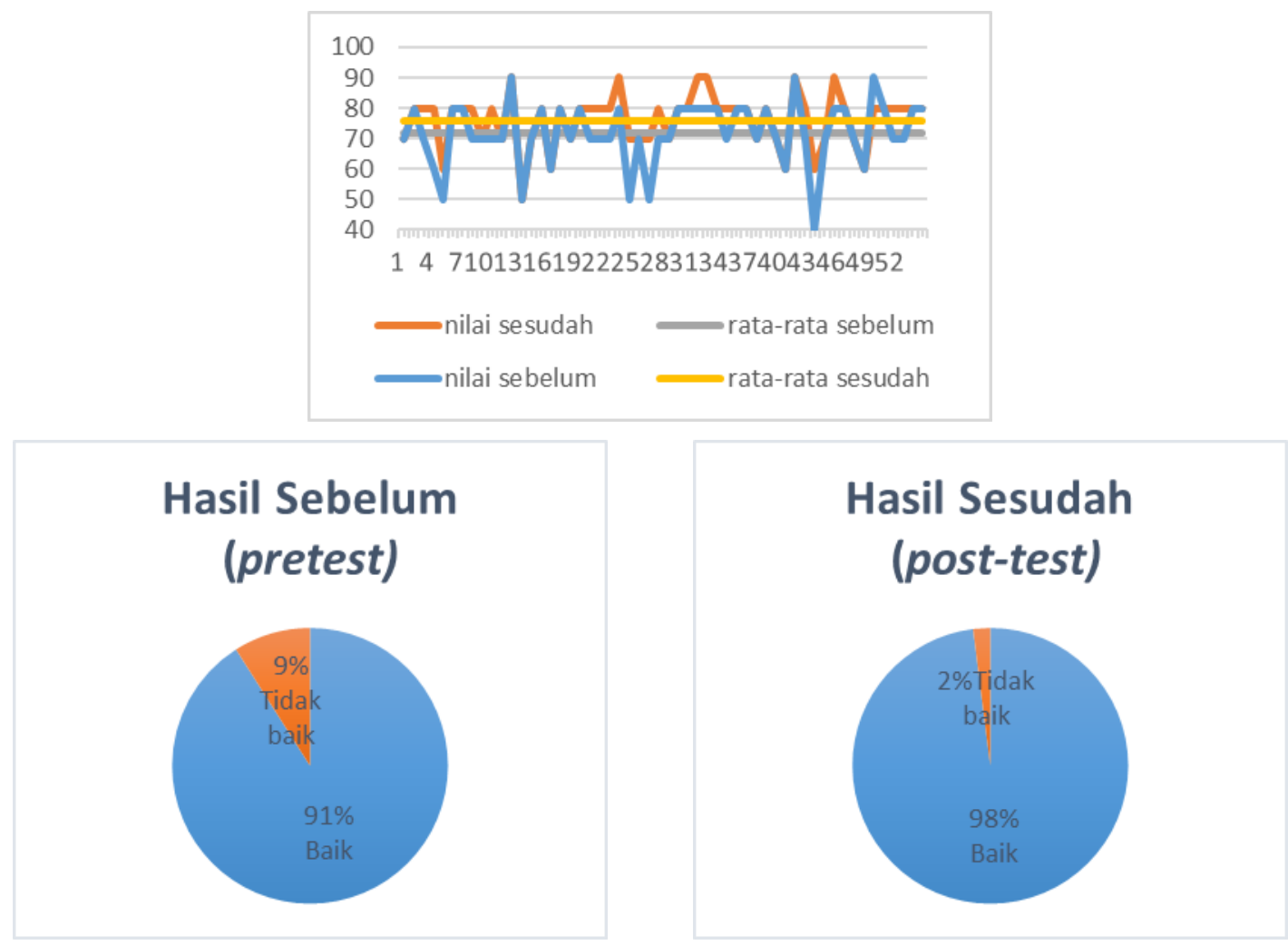

Figure 1: Diagram of students' knowledge about flood disaster mitigation

\section{Conclussion}

From the results of our research and based on the background of the area used for the study, students in grade 6th at Bojong Asih 01 Elementary School and Bojong Asih 02 Elementary School in Dayeuhkolot already know a lot about disaster mitigation because almost every year floods occur in the area. But not a few also are still lacking knowledge about flood mitigation. After the socialization of disaster mitigation that we do, almost all students can understand the importance of disaster mitigation in the Citarum Watershed.

Our advice that can be done in the future are

1. conduct regular disaster mitigation socialization so that students in the Citarum Watershed understand the importance of disaster mitigation evenly, and

2. use a variety of more creative socialization media to increase student enthusiasm and to be easily understood. 


\section{Acknowledgments}

Thank you to the Dean of the Faculty of Mathematics and Natural Sciences, and the Directorate of Research, Community Service, and Innovation, Universitas Padjadjaran, who have provided Community Service Grants funds with contract Number: 3453/UN6.D/PM/2019.

\section{References}

Adi, S. (2013). Characterization of flash flood disaster in Indonesia. Indonesian Journal of Science and Technology 15(1), 42-51.

Alexandra, L.A. (2015).Perception of Human Security: Indonesian View, in Human Security in Practice: East Asia Experiences JICA-RI Working Paper, No. 99. Tokyo: JICA Research Institute.

Bainus, A., Yulianti, D., and Husin, L.H. (2020). Mitigating Natural Disaster in the Midst of Limitations: Human Security Issues in Overcoming Threat of Flood in Citarum River Basin, Indonesia. Humanities \& Social Sciences Reviews, Vol 8, No 3, 2020, pp 859-867.

Bambals, R. (2015). Human security: An analytical tool for disaster perception research. Disaster Prevention and Management, 24 (2),150-65.

Chalkias , C., Ferentinou, M. \& Polykretis , C., (2014). GIS-Based Landslide Susceptibility Mapping on the Peloponnese Peninsula, Greece. Geosciences, Volume 4, 176-190.

Hassani, W. (2016). Flood disaster risk analysis in Majalaya district, Bandung Regency (Unpublished master dissertation). Department of Geography Studies, UniversitasPendidikan Indonesia.

Jimba, M., Hubbard, S., Sase, E., Suzuki, T., and Otsuka, K. (2011). Human security approaches for disaster recovery and resilience. $J M A J, 54(5)$, pp. 38-341,

Kablan, M.K.A., Dongo, K., and Coulibaly, M. (2017). Assessment of Social Vulnerability to Flood in Urban Côte d'Ivoire Using the MOVE Framework. Water 2017, 9, 292; 1-19. doi:10.3390/w9040292

Manfreda, S., Sole, A. \& Di Leo, M., 2011. Detection of Flood-Prone Areas Using Digital Elevation Models. Journal of Hydrologic Engineering, pp. 781-790.

Muin, S. F., Boer, R., and Suharnoto, Y. (2015). Flood modeling and analysis of losses due to flood disasters in the Upper Citarum watershed.Jurnal Tanah danIkliim, Vol 39 (2),

Pitsuwan, S. and Caballero-Anthony, M. (2014). Human Security in Southeast Asia: 20 years in Review. Asian Journal of Peacebuilding, 2(2), 199-215

Sarminingsih, A., Soekarno, I., Hadihardaja, I.K., and Syahril, S.B. (2014). Flood Vulnerability Assessment of Upper Citarum River Basin, West Java, Indonesia. International Journal of Applied Engineering Research, 9 (23). 22921-22940. 
Tauhid, C.D.L., Fathani, T.F., and legono, D. (2017). Multi-Disaster Risk Analysis of Klaten Regency, Central Java, Indonesia. Journal of the Civil Engineering Forum, Vol. 3 No. 3 (September 2017), 135-148. 